\title{
THE SCOPE OF APPEAL IN CRIMINAL CASES
}

\section{Lester B. Orfield †}

There are few more fascinating tasks than tracing the development of what matters appellate courts will consider on review. This is particularly true as to criminal cases, where the development has been so much slower than in civil cases despite the greater interests at stake. In the course of its long development appeal has grown from review of the old common law record to review of all issues of law whether apparent on the record or not, review of issues of fact as well as of law, review of the propriety of the sentence, and review of matters not objected or excepted to in the trial court or assigned as error or considered in appellant's brief.

The earliest appellate review surviving into modern times was by writ of error. On such writ the upper court could review only errors apparent on the record. The record included only the process, the pleadings, and the judgment, together with various entries made by the clerk. It did not include the testimony and exhibits, the rulings on admissibility of evidence, or the instructions of the court. Since errors were more likely to be of the latter type, the writ of error had a very narrow range of usefulness.

Because of this most serious disadvantage there was developed as early as I285 the bill of exceptions, provided for in the Statute of Westminster. ${ }^{1}$ When in the course of a trial a party objected to a ruling of the court he would have that fact written down, and the judge would sign and seal it. The appellate court would then have the power to consider such exception. Later on, with the development of shorthand and stenography, the bill of exceptions would be drawn up as a single unit at the end of the trial instead of in parts and during the course of the trial as formerly. Unfortunately, the bill of exceptions as developed in England was allowable only in civil cases. So for several centuries review of criminal cases in England was narrowly confined to errors of law apparent on the record.

Eventually, however, a practice sprang up of the reserving of cases by the trial court for the consideration of the judges of the superior courts. The latter courts might review such legal errors as were reviewable in civil cases on bill of exceptions. This practice of stating a case received formal legal recognition in 1848 when the Court for Crown Cases Reserved was established. But since the stating of a case lay in the discretion of the trial

†A. B., 1924, LL.B., I927, University of Minnesota; M. A., I928, Duke University; S. J.D., I929, University of Michigan; Brandeis Research Fellow, I933-34, Harvard University; Associate Professor of Law, University of Nebraska College of Law, on leave of absence; Senior Attorney, Social Security Board.

I. I3 Edw. I. See John Raymond, The Bill of Exceptions (I846). 
court it was not a wholly satisfactory remedy. It was seldom used in practice.

In the United States some of the earlier cases asserted that on writ of error the appellate court might review only errors apparent on the record. ${ }^{2}$ This practice was subsequently altered by decision or by statute so as to admit of review of other errors of law committed during the course of the trial." In some states "appeals" might be taken in addition to writs of error, or they were substituted for writs of error. In most cases, however, this did not result in increasing the scope of review. The term "appeal" was taken over from the chancery system of review, where an appeal in equity involved a rehearing of the case and the appellate court reviewed both the facts and the law. But by judicial interpretation the term "appeal" as applied to review of common law civil cases and of criminal cases was held to permit review only of issues of law. ${ }^{4}$ As a matter of fact, so confused were some courts by the use of the term "appeal" in non-chancery cases that in deciding chancery cases they felt themselves entitled to review only issues of law. In many states new evidence was not admissible even in chancery appeals. The mere fact, then, that the statutes in a number of jurisdictions used the term "appeal" did not mean that the appellate court might review the whole case both as to the law and the facts. To review the facts a statute or constitutional provision in express terms conferring upon the court the power to do so was apparently necessary. ${ }^{5}$

\section{Review of THE FaCTS}

Perhaps the greatest step in the development of the scope of review in modern times has been that of allowing the court to review the facts. ${ }^{6}$ This power had long been exercisable in France and other European countries with judicial systems modelled after hers. ${ }^{7}$ The Criminal Appeal Act conferred this power in England, subject, however, to obtaining the consent of the trial court or the Court of Criminal Appeal. It has existed in civil cases at common law since $I 873 .{ }^{\circ}$ It had long been the rule in equity,

2. Mitchell v. State, 3 Mo. 283 ( 1833 ).

3. People v. Palmer, I09 N. Y. 4I3, 4I8, x7 N. E. 213 , $2 I_{5}$ (I888).

4. Baldwin, The Amierican Judiciary (Ig05) 280, 28 I.

5. As to the scope of review on appeal in civil cases in most states see statement by Jos. P. Blair concerning letters from chief justices in thirty-one states (IgIO) LA. BAR Ass'N REP. 39.

6. It has been pointed out that there are two services, both judicial, which the courts can render but which they have failed to render in the past: The trial courts may render declaratory judgments, and appellate courts may review cases on the merits. Sunderland, Improving the Administration of Justice (I933) I67 ANNALs 60, 61.

7. Woods, The French Correctional Courts (1932) 23 J. CruM. L. 20, 24. Such is the Iule in Germany, [Liewellyn, Tege Bramble Bush (I930) 28] and in Spain, [Baldwin, THE AMERICAN JUDICtARY (I905) I5I]. Though it does not exist in strict theory in Russia, the grounds of appeal are so broad that the same result is arrived at. ZELITCE, SovIET ADMINISTRATION OF CRIMINAL LAW (I93I) 271, 273.

8. Although the Common LAW PROCEnURe Acr of I854 provided for waiver of jury trial, it was nevertheless held that issues of fact could not be reviewed. 
although new evidence could not be considered. ${ }^{9}$ It has been asserted that the slowness of the English development was because issues of fact were determined by the jury and issues of law by the court, whereas on the Continent both issues were determined by the court. ${ }^{10}$ It has also been pointed out that the broad review in equity cases was due to the dominant position of the King when the chancery system was developing. ${ }^{11}$

Before going any further it seems well to attempt a definition of review of the facts. This can be partly accomplished by a process of exclusion, namely, by setting out what is embraced within the term issue of "law". Clearly, a review of errors appearing in the ancient record, errors concerning the indictment, the plea, and the verdict was a review of legal errors. Likewise, issues as to the admissibility or the exclusion of evidence or the refusal or granting of instructions by the court involved questions of law. The same was true of review of the rulings on various motions and on the legality of the sentence.

Suppose, however, that the defendant seeks review on the ground that there was no evidence to support the verdict or that a verdict should have been directed, or on the ground that a new trial was refused although the verdict had no evidence to support it. The inventions of modern stenography made it possible to do this easily. Do we now have an issue of fact? Certainly, if the evidence were very close, say sixty per cent. on one side and forty per cent. on the other (if it could be measured thus), any attempt by the appellate court to evaluate the weight of the evidence would look very much like reviewing the facts. On the other hand, if no evidence or very little evidence were presented against the defendant, and much or, for that matter, no evidence were presented in favor of the defendant, while in reality the court would be reviewing the facts if it reviewed the case, it is not hard to say that the court is reviewing an issue of law. ${ }^{12}$ In other words, an error of law is always committed when the great weight of the evidence is against the verdict. ${ }^{13}$ True, the appellate court in arriving at the conclusion that the verdict is against the weight of the evidence has to review the facts. But does it not likewise also review some facts in deciding whether any other errors of law were committed? Can there be any application of any principle of law without first looking at the facts to

9. See (1927) 36 Yale L. J. 570.

Io. Sunderland, The Proper Function of an Appellate Court (1930) 5 IND. L. J. 483, 487.

II. Goodnow, The Writ of Certiorari ( $189 \mathrm{I}$ ) 6 PoL. Scr. Q. 493, 5 I5.

12. But see the statement of Henry Cohen, Review of Law and Facts in the New York Court of Appeals (I933) 33 CoL. L. REv. 953, 956: "The ideal of a Court of Appeals solely to expound the law, the facts being somehow given and uncontrovertible, was finally achieved in the Constitution of 1895 . Provision was there made without exception that only questions of law could be reviewed in the Court of Appeals. So determined was the purpose to free the court of what must have been considered the taint of reviewing facts that the question of whether there was any evidence to support a finding, a question of law, was also withdrawn from the province of the Court of Appeals if decided unanimously by the court below."

13. Baldiwin, The A Mierican Judictary (Ig05) 259. 
which they are to be applied? Could a legal system be today conceived in which a verdict against the weight of the evidence would not be treated as an error of law? ${ }^{14}$ Perhaps it is true that this occasionally is used as a basis for reviewing the facts even when they are balanced almost evenly. ${ }^{15}$ If the latter be thought undesirable, it must be palliated as an unavoidable by-product of an admittedly desirable type of review.

The sort of error which has just been considered is, or is dealt with, as an error of law. An error of law is committed when the judge refuses to set aside a verdict against the clear weight of the evidence. When the evidence is almost evenly divided the judge commits no error in refusing to set aside the verdict, since it is the function of the jury to pass on the facts. ${ }^{16}$ The defendant is entitled to have the verdict set aside only when it is palpably erroneous. As a consequence, in all but the clearest cases the defendant has only the discretionary power of the trial court to fall back on as to errors of fact, and he can obtain no relief in the appellate court. ${ }^{17}$

How, then, does review of the facts differ, if at all, from review of the weight of the evidence? One writer has suggested that it means a review of the credibility of witnesses. ${ }^{18}$ That is to say, the jury or the trial judge may have chosen to believe what certain witnesses said; nevertheless, the appellate court may choose to believe the contrary. Such appeal might involve an entire rehearing of the case, though it may seem a bit anomalous on first impression to regard such a rehearing as an appeal when it looks so much like another trial. Since the object of even so broad a review is to correct the injustice originally done, it is submitted that the term appeal is properly applied, however. Or such appeal might involve new testimony in the appellate court on certain phases of the case or the re-examination of some of the witnesses heard in the original trial. None

I4. In People v. Helmer, r54 N. Y. 596, 49 N. E. 249 (1898), 7 YALE L. J. 278, O’Brien, $\mathrm{J}$., dissenting, stated that whether there is any evidence to sustain the verdict has been considered as purely a question of law ever since the decision of Lord Mansfield in Carpenter's Co. v. Hayward, I Doug. 373 (I780). That it is only seventy or eighty years old is asserted by Hough, The Review of Criminal Causes in the Courts of the United States (1926) 3 LECT. LEGAL TOPICS $49,63$.

15. It has been suggested that writs of error were influenced by the equity appeal so as to cause the common law courts to permit new trials for glaring errors of fact under the disguise of the fiction that such errors were errors of law. Sunderland, The Proper Function of an Appellate Court (1930) 5 InD. L. J. 483, 488.

16. Hough, The Review of Criminal Causes in the Courts of the United States (I926) 3 Lect. LeGal Topics $49,53,55,63$.

It has been urged that the only question of fact that should be left to the appellate court is whether or not the evidence on the part of the state makes out a prima facie case. Deemer, Proposed Reforms in Criminal Procedure (1907) 4 PROC. AMr. PoL. ScI. Ass'N 246, 255; Smyth, The Limitation of the Right of Appeal in Criminal Cases (Ig04) I7 Harv. L. REv. 317,330 . 63.

17. Sunderland, Improving the Administration of Civil Justice (1933) 167 ANnaLs 60,

18. Green, Judge AND JURY (1930) 385; Atkin, Appeal in English Law (I927) 3 CAMrb. L. J., I, 8. See also Note (Ig28) I6 Calif. L. Rev. 500, 5 II ; Lleweltiyn, The Bramble BUSम (I930) 28. 
of these things would be admissible under our present system when verdicts are set aside as contrary to the weight of the evidence.

Appeal on the facts, then, presents three or four possibilities as to the scope of review. ${ }^{19}$ In its narrowest form it might mean simply that the appellate court would examine all the facts set out in the full record of the proceedings below. ${ }^{20}$ In its broadest form it might mean a complete retrial of the case. In an intermediate form, and the form in which it is most commonly referred to in England, it would mean review of the whole record, with a power in the appellate court to call new witnesses where there is doubt, or obscurity, or overlooking. ${ }^{21}$ A slight variant of review merely of the full record is to allow the appellate court to receive evidence not offered below provided the issue is "capable of proof by record or other incontrovertible evidence." 22 A highly interesting, but perhaps impracticable, proposal is that of permitting the appellate court, like the pardoning authority, to call on the prosecuting attorney or on the police directly to make inquiries for their information. ${ }^{23}$

\section{Arguments in Favor of Review of Facts}

What are the considerations which enter into the question of the desirability of appeal on the facts? On behalf of such appeal the major consideration unquestionably is that it makes possible an appeal on the merits. The errors in the judgment, not the judge, are corrected. Mistakes on the facts can be just as prejudicial, or even more prejudicial than mistakes of law. A tribunal which can review only errors of law is crippled to that extent. Technical decisions are likely to result. ${ }^{24}$ A tribunal which can also review the facts has attained the fullest growth possible. Theoretically

I9. The various alternatives are nowhere better pointed out than by JEREMr BENTHAMr, 2 COLLECTED WORKS 56: "Of appeal in highly criminal cases, in general, what shall be the effect? The appellate judicatory-shall it pronounce the decree upon the bare view of the evidence, as reported from the immediate judicatory?-shall it, of course, try the cause over again, by hearing evidence as if none had before been given?-or shall it have the option between the reported evidence and the giving a fresh hearing to the evidence? On the choice between these three courses, it is manifest how much would depend, and how considerable between them respectively might be the difference in point of effect."

20. It is recommended in this sense by Sloss, Reform of Criminal Procedure (IgrI) I J. CrIM. L. 705, 709; Atkin, L. J., of the English Court of Appeal points out that while there are few appeals on pure fact, there are a considerable number of cases in the Court of Appeal which turn on the question whether there was sufficient evidence to support the conclusion of fact. Atkin, Appeal in English Lawe (I927) 3 CaMr. I. J. I, 8.

$2 \mathrm{~T}$. A limited variation of this is to permit the calling of witnesses or reception of affidavits as to questions of fact relating to procedure at the trial. This is proposed in the MIsSOURI CRIME SURVEY (Ig26) 368.

22. Report of Committee $E$ of American Institute of Criminal Law and Criminology (Igro) I J. Crim. L. 584, 591; SCOTT, FUNDAMENTALS OF ProcedURE (I922) I57; (I927) 36 YALE L. J. 570.

23. Heraran Cohen, The Criminal Appeal Acr (1907), introduction by Sir Henry B. Poland, I6.

24. In order to find out whether error has been prejudicial the facts must be examined. If the court can review only issues of law it cannot look at the facts to see whether errors have been prejudicial. Hebert, The Problem of Reversible Error in Lonisiana (1932) 6 TuLANE L. REv. 169, I75. 
at least, a tribunal so empowered should be capable of dealing justly with an appellant to the fullest extent that justice can be brought about through judicial machinery. When in practice such a tribunal does fail to attain a just result the defect cannot be charged to any want of legal power in the court. The Sacco-Vanzetti Case is perhaps the best known recent case in point indicating the need of a power to review the facts. ${ }^{25}$

That mistakes of fact will occur is inevitable. There may be a mistaken identification arising out of the victim's and even the witnesses' desire for vengeance. The jury may draw false conclusions from circumstantial evidence. The witnesses may have committed perjury. Prosecuting attorneys are often incompetent and overzealous. The public may be impatient when there has been a "crime wave". Prior convictions may be prejudicial in their effect. The "third degree" may have been used. The police may have made suggestions to witnesses. The defendant may have had no attorney, or had a poor one. The trial judge may not have commented on the evidence $^{26}$

Mistakes of fact may be much more prejudicial than mistakes of law. ${ }^{27}$ Mistakes of fact may go directly to the innocence of the defendant. Mistakes of law are often purely technical and, even though more than technical, result in a new trial and not the release of the defendant, as he may be guilty no matter how substantial the error of law. However, mistakes of fact as to innocence are not so likely as mistakes of law. ${ }^{28}$ An absolute right to review of the facts, if carried to the extent of admitting testimony in the appellate court and not merely a review of the full record, would make the court another trial court, and even the lesser task of reviewing the full record would strain the courts. ${ }^{29}$

Another advantage of review of the facts is that the court is no longer troubled with what is an issue of fact and what of law. There is no clean cut distinction between the two. In the law of pleading the line is hard to

25. Morgan, book review of EmRMan, The UNTRIEd CASE, Book Note (1934) 47 Harv. L. Rev. 538, 546. As a result of these cases it was recommended that the Supreme Judicial Court be given the power in capital cases to review the facts, in the Mass. Judicial Council, 3d Rep. (1927) 40. See (1929) I5 A. B. A. J. 77; Hale, Memorandum In re the Sacco and Vanzetti Case Submitted to His Excellency Governor Fuller (I927) I2 MAss. L. Q. No. 6 , pp. I-I3; Report of Attorney General Reading (I928) I3 MASs. L. Q. No. 3, Sup. 6; (1928) I3 Mass. L. Q. No. 3, p. 49; Recent Social Trends, c. 28 of CIark and Douglas, Law and LEGAL INSTITUTIONS (I932) 1460.

26. Some of these factors were usually present in the cases set out in BorcEARD, ConVICTING THE INNOCENT (I932).

27. In 1883 the proposed Criminal Appeal Bill by Lord Herford gave the defendant an absolute right to review on the facts with a conditional right as to law. Sibley, Appeal on Matter of Fact in Criminal Cases (Ig07) 32 LAW MAG. \& REv. 3I4, 332.

28. Compare, however, the view of JEROME FRANK, LAW AND THE MODERN MiND (1930) page I06, quoting the views of Justices Miller and Pitney of the U. S. Supreme Court. Mr. Chief Justice Fuller once stated that few appeals in capital cases from the lower REC. 3285 ( 1892 ).

29. Proposals to confine the appellate court to errors of law in civil cases were severely criticized in Louisiana (I9I0) LA. B. Ass'N REP. 39, 40, 53, 65, 87 . 
draw between conclusions of law and of fact. Similarly in criminal law, equity and quasi-contracts great difficulty is encountered in distinguishing mistake of fact from mistake of law. It has several times been pointed out that appellate courts seem to take jurisdiction or not as they choose and rationalize their acts by applying the label of law or fact as is needed. ${ }^{30}$

\section{Arguments Against Appeal on the Facts}

On the other hand, serious objections stand in the way of appeal on the facts. The appellate court cannot as conveniently pass on the facts as the lower court. ${ }^{31}$ The jury and the trial court had the advantage of seeing and hearing the witnesses personally. ${ }^{32}$ The cold printed record inevitably must give an incomplete and distorted picture of the case. Where the testimony is not in substantial conflict there may be little difficulty on review; but where there is such a conflict, review is difficult. To make the appellate court a second trier of the facts amounts to a second trial of the case. The trial in the lower court is closer in time and place to the commission of the crime. Reconsideration in the upper court might come at a much later date, particularly in jurisdictions where the defendant has a long period in which to take his appeal, a long period to prepare his bill of exceptions, and the appellate court is so congested that a long time elapses before submission and the rendering of the court's opinion. Witnesses may have disappeared. It may be very inconvenient for the appellate court to get a view of the scene of the crime in cases where that is desirable.

Not only is it true that the trial court has a better opportunity to get at the facts, but it is extremely inconvenient for an appellate court to review facts. Its dockets are already crowded. It has its hands full merely determining issues of law. Its present machinery is adapted to the consideration of legal issues; that is its specialized function. To ask it to do something else may result in the latter being poorly done and a deterioration of its work on purely legal issues. It has been seen that the appellate court is at a disadvantage both as to time and place in comparison with the trial court. Review of the facts is extremely tedious and often a pure waste of

30. Clark, The Neze Illinois Civil Practice Act (1933) r U. of Car. L. REv. 209, 222; Atkin, L. J., Appeal in English Law (1927) 3 CAMr. L. J. I, 8.

3I. It has been pointed out, however, that as to written evidence or affidavits, an appellate court is in as good position as the trial court to review. See Note (I928) I6 CALIF. L.
REv. 500 .

32. Atkin, L. J., Appeal in English Law (1927) 3 CAмr. L. J. I, 8. See the statement by Pound in Faulkner v. Simms, 68 Neb. 295, 301, 94 N. W. II3, I14 (I903): "It goes without saying that, in general, the trial judge has a great advantage in that he sees and hears the witnesses. Moreover, he commonly knows more or less of their general character and standing, and may have a general local knowledge as to matters referred to in evidence and surrounding circumstances which enables him to weigh conflicting evidence with much greater assurance of reaching a correct solution than is probable in the revising court. Hence, in ordinary cases where the evidence is entirely oral and the trial court may be presumed to have had a general knowledge of the parties, the witnesses and the subject of controversy, the finding of the trial court is entitled to almost decisive weight." 
time. Already the courts are overburdened with voluminous records which they have to examine to get at merely legal issues. Review of the facts serves neither the function of maintaining trial court standards nor of developing the law of the jurisdiction.

The best case for confining review to issues of law can be made out as to the highest appellate court where there are intermediate appellate courts to which appeals must first be taken. If the intermediate court should be empowered to review both facts and law, one review of the facts is thus secured; and the highest court should confine itself to maintaining the standards of the trial courts and laying down the law of the jurisdiction. A double review of the facts would be unnecessary, and the highest court would be occupied with the decision of legal issues. The Supreme Court of the United States ${ }^{33}$ and the New York Court of Appeals may properly be limited to the decision of legal issues. ${ }^{34}$ If criminal appeals go directly to the court of last resort, however, review should not be thus limited.

It has been argued that appeal on the facts is objectionable because the jury is no longer left as the final arbiter of the facts. ${ }^{35}$ But from the earliest days there has been an increasing control by the courts over the jury. ${ }^{36}$ And certainly the vaunted sovereignty of the people in the form of the jury should not be carried to such lengths as to permit the conviction of innocent defendants. Trial by jury is principally designed to secure protection for the defendant. ${ }^{37}$ Hence, when the defendant himself wishes on appeal to assail its findings it cannot reasonably be argued that the right to trial by jury is thereby impaired. ${ }^{38}$ The fact is that juries make mistakes, and such mistakes should be open to correction at the suit of the defendant

33. Frankfurter \& Landis, The Business of the Supreme Court (Ig27) 290.

34. Henry Cohen, Review of Law and Facts in the New York Court of Appeals (I933) 33 Cos. L. REv. 953, 954 .

35. Taylor, Murder Cases and the Practice Relating Thereto in the Court of Appeals (I924) LECT. LeGAL Topics 4I3.

36. "It may be asked, why should the court's idea of reasonableness prevail over that of the jury. Perhaps for the same reason that our English forbears devised the attaint, the fine, the demurrer, the new trial, indeed the directed verdict itself; the experience of five hundred years had proved that an uncontrolled jury didn't work. Certainly it has been the prevailing opinion for over a hundred years that an unreasonable verdict should not stand, and the court has always decided the question of reasonableness. Not since the attaint has the reasonableness of a verdict been left to a jury." Smith, The Power of the Judge to Direct a Verdict: Section 457a of the New York Civil Practice Act (I923) 24 Cot. L. Rev. IIr, r24.

37. However, in People v. Scornavache, 347 I11. 403, I79 N. E. 909 (I93I), the court has held that the state may insist on a jury trial. See (I932) 27 ILI. L. Rev. 447; Hall, Has the State a Right to Trial by Jury in Criminal Cases? (I932) I8 A. B. A. J. 226.

38. State v. Knight, 96 N. J. L. 46I, II5 Ati. 569 (Ig2I). But see the concurring opinion of Kalisch, J., at 96 N. J. L. $46 \mathrm{I}$, 477, II5 Atl. 569, 575, citing I BISHop, CRIM. PROC. 892 and State v. Mead, 4 Blackf. 309 (Ind. I837). As concerns the federal courts the Seventh Amendment requiring re-examination of finding of jury only according to the common law may forbid review of the facts in any broad sense. Amidon, The Quest for Error and the Doing of Justice (I906) 40 AM. L. REv. 68I, 685. 
Despite the serious objections to review of the facts which have just been discussed, it is believed that one such review should be available. ${ }^{39}$ In the first place, while the number of cases where such appeal may be necessary may not be great, it cannot be doubted that such cases do occur. A very small number of such cases would justify such a power. In the second place, the possibility of such review is necessary to maintain popular confidence that justice is and can be done within the regular operation of the judicial system. Few things could be more calculated to impair the popular faith in the courts than an admission by an appellate court that it cannot do justice in the case because it cannot get at the merits. The mere existence of the right to such review does not mean that the appellate court will be turned into a second trial court. ${ }^{40}$ Finally, a review of the whole case makes it possible to dispose of the case without the need of a new trial and possible subsequent appeals. ${ }^{41}$

Such appeal may be hedged about with limitations of a kind to prevent its abuse. ${ }^{42}$ For instance, in England it does not lie of right but only in the discretion of the trial court or the Court of Criminal Appeal.43 Thus the appellate court need give its time only to such cases as have some probable basis. The defendant is thus prevented from resorting to such appeal for purely frivolous reasons, such as obtaining a delay. If the defendant wishes to introduce new evidence he should be compelled to show why he did not introduce such evidence in the trial court. If he did not testify himself or if his witnesses did not testify there, he should be compelled to show good reason why he or they should now be allowed to testify. The English cases show that the introduction of new evidence is relatively

39. Such appeal is recommended in RhPort on CrIminar Procedure (rg3I) Nat. CoMm. on LAW OBSERVANCE AND ENFORCEMENT 42, 44. The report is criticized by Miller, The Report on Criminal Procedure (I932) I8 A. B. A. J. 453, 455, who says: "One looks in vain for any consideration of the best interests of society as a whole in this particular part of the report." But is not society interested in avoiding the conviction of innocent persons?

It is also recommended by STONE, LAW aNd ITS ADMINISTRation (IgI5) 208; Roberts, Trial Procedure-Past, Present and Future (I929) I5 A. B. A. J. 667, 670; BoRCHARD, ConVicting the Innocent (1932) xxi, 13; Gemmill, Procedure in Criminal Courts (I912) $3 . \mathrm{J}$. CRIM. L. I75, I92.

40. Avory, J., said in Rex v. Cotton, I5 Cr. App. Rep. I42 (Ig2I) that the Court of Criminal Appeal "sits only to determine whether justice has been done and not for the retrial of criminal cases."

4I. Scott, Fundamentals of Procedure (1922) 157; Clark, History, Systemis and Functions of Pleading (I925) II VA. L. REV. 5I7, 550 .

42. Roberts, Trial Procedure-Past, Present and Future (I929) I5 A. B. A. J. 667, 670. Dean Clark suggests with reference to civil appeals that if the English system of appeal on the facts is adopted, there should not be a formal and formidable printed record and that the appellate court be furnished with special copies of the evidence; and that appeal fees would prevent abuse. See Clark, The Neze Illinois Civil Practice Act (I933) I U. of CEI. L. REv. 209, 222. See also (I927) 36 YALE L. J. 570.

43. As introduced in I906 appeal, would have been of right. PoLAND \& CoHen, The Criminal Appeal Bill Examined (ig06) $\mathrm{r}$. It is arguable that appeal of leave involves as much expenditure as appeal of right. That is to say it is difficult for the appellate court to grant a review on the facts without reading the record. In many cases, however, no transcript of the testimony goes up but simply the judge's notes or report. 
rare. ${ }^{44}$ In France where new evidence may also be introduced the right is rarely relied upon. ${ }^{45}$ In the German civil appellate system abuse of the right to introduce new evidence did not result in its abolition but merely in the imposition of restrictions. ${ }^{46}$

Thus, starting with no review of the facts in the United States and full review in Germany, the tendencies in the two countries have been in opposite directions. The United States has tended to widen the scope of appeal on the facts, ${ }^{47}$ while Germany has tended to narrow it. The ideal goal is to attain a happy medium between being too slow to interfere with the verdict of the jury, thus necessitating application to the executive for a pardon, and being too ready to interfere and thus impairing the position of the jury in criminal trials. ${ }^{48}$

To make the right to appeal on the facts effective the appellant should be permitted to be present at the hearing in the appellate court. In England he may be present at the final hearing if leave to appeal is granted. Where appeal is merely as to the facts as they appear in the record or on issues of law only, no purpose is served in having the defendant present at the hearing of the appeal.

The American Law Institute Code of Criminal Procedure cannot be said to provide for review of the facts in the English sense. ${ }^{49}$ Under the Code the appellate court is to review the evidence to determine whether it is sufficient to support the judgment where this is a ground of appeal. It may review the evidence whether its sufficiency is a ground of appeal or not. In capital cases it must review the evidence to determine if the interests of justice require a new trial, whether the insufficiency of the evidence is a ground of appeal or not. No provision is made to hear new evidence at the hearing of the appeal. The appellate court is confined to examining the facts set out in the record.

The cynical, or perhaps the realistic, critic may ask, what difference does it make whether an appellate court is formally empowered to review the facts or not? Does not the court decide on the merits anyhow? That is to say, the court can usually find some errors of law and formally reverse on the basis of them, though in reality it reverses on wholly different con-

44. Atkin, Appeal in England (I927) 3 CAMrs. L. J. I, 8. It has been asserted that the New York Court of Appeals rarely sets aside the findings of the jury. Taylor, Murder Cases and the Practice Relating Thereto in the Court of Appeals (I924) Lect. Legar TopICs, 407, 4I3.

45. 6 Helie, Traité de l'Instruction Criminedie (6th ed. i867) §2984; Garraud, Précis De Droit CRIMINer (I4th ed. I926) § I004. 708.

46. Millar, The Recent Reforms in German Civil Procedure (I924) Io A. B. A. J. 703,

47. However, although the Illinois appellate court had exercised the power for thirty years, the supreme court held that it had no such power when the question was presented to it. GREEN, JUDGE AND JURY (I930) 385, ก. 2.

48. This is pointed out by Craies, Criminal Appeal in England (Ig07) 8 J. Soc. Comp. LEGIS. N. S. 93, IO3.

49. Section $457(2)$. 
siderations. ${ }^{50}$ It is submitted, however, that this point of view is untenable. In the first place, not all, nor perhaps most, judges adopt so sophisticated a point of view, though doubtless nearly all judges are unconsciously affected by the merits of the case. In the second place, such decisions do not develop the law of the jurisdiction; indeed, they tear it down. Appellate courts subject themselves to being called technical when they assign such reasons. The law and the practice should be brought into harmony by express authority to review the facts. "Justice ought not to be insincere or accidental." 51

\section{REVIEW OF THE SENTENCE}

In bygone days major emphasis was laid on the conviction of the criminal. What happened to him after conviction was little heeded. The public lost interest in the criminal after the finding of the verdict of the jury. At a time when two hundred offenses were punishable by death the problem of uniformity was not likely to arise. But when other punishments were provided and when the courts were empowered to impose sentences within maximum and minimum limits, attention was inevitably attracted to disparities between sentences where the crime or the circumstances were essentially the same.

An appellant may wish review of his sentence for either or both of two reasons. He may claim that it is illegal. Or though legal, he may claim that it is unfair. One might suppose offhand that an appellate court could

50. "Because upper court decisions are based upon printed records (which the judges presumably read at their leisure, free from the distracting sounds and sights of the trial court room) and because such decisions are accompanied by opinions which purport sufficiently to state 'the facts' and purport to apply thereto, in most cases, stereotyped 'rules of law', it is possible to argue plausibly that the personal element is negligible in the work of appellate courts. The writer believes that such a notion is mistaken. . . . Suffice it to say that internal evidence in the opinions and revelations of outspoken judges go to show that justice creeps into the work of appellate courts: (a) through the determination of the 'facts'; (b) because the courts often decide first and then arrange their 'facts' and 'rules' so as to justify the decision previously arrived at; (c) through the vagueness and multiplicity of their rules." Jerome Frank, Are Judges Human? (I93I) 80 U. of PA. L. Rev. 17, 29.

"Practically every decision of a lower court can be reversed. By that I mean practically every record contains some erroneous rulings. Therefore, although appellate courts may insist that they are not concerned with general results, that it is not their function to pass on the facts, and that they are limited to a review of the points of law ruled upon by the court below, they can nearly always find some error if they want grounds of reversal. And the human mind being what it is, there is not the slightest doubt that appellate courts do find substantial error in a record when the case seems to them to have been decided unjustly or unwisely; whereas the same error would have been passed over as trivial if the decision had seemed wise and just." Ulman, A JudGe TAKES THE STAND (I933) 265, 266.

"A large percentage of the criminal cases are retried by the appellate court as a contrt of first instance. The court may examine the record, become a second jury, making up its mind first as to guilt or innocence. Then, having decided that, it disposes of the writ of error upon that basis but giving 'legal reasons' therefor. And if the evidence as it appears to the judges shows no guilt, beyond a reasonable doubt and the court wants to reverse, it is very easy to find some instructions (out of ten or twenty pages of them) repetitious, inaccurate, unnecessary, misleading, inapplicable, argumentative or disjointed." Newman F. Baker, Reversible Error in Homicide Cases (I932) 23 J. CRIM. L. $28,30$.

5I. Report on UNFaIRNESS in Prosecutions (I93i) Nat. Comm. on Law ObSERvance AND ENFORCEMENT 346 . 
certainly correct an illegal sentence. Such seems not to have been the early view, however. All that the appellate court might do was to affirm or reverse. ${ }^{52}$ Hence, when it reversed for illegality it could not itself impose a legally correct sentence but must send the case back to the lower court for retrial. $^{53}$

Sending back for new trial was better, however, than an absolute reversal of the conviction. But it was absurd to retry a guilty defendant. A step in advance was to send the case back to the trial court for imposition of the correct sentence. This was similar to the rule developed with respect to the omission of the allocutus; the appellate court would send the case back, not for retrial, but for the sole purpose of taking the allocutus. ${ }^{54}$ The ultimate step was by statute to permit the appellate court to correct the sentence itself. ${ }^{55}$ In England review of the legality of the sentence, peculiarly enough, is only of leave, just as is review of its propriety.

Vastly more complicated is the problem of review of the propriety of sentences. Where the sentence is illegal it is easy enough for the appellate court to substitute a legally correct one. Where the sentence is admittedly legal but the defendant questions the amount or kind of punishment, however, an appellate court which takes its duties seriously is faced with a multitude of imponderable questions. The power to pass on the propriety of sentences exists by virtue of statute in a number of states. ${ }^{50} \mathrm{~A}$ few state courts have assumed the power without any statute. ${ }^{57}$ The federal courts have no such power. ${ }^{58}$ The Court of Criminal Appeal in England passes on the propriety of sentences, provided that leave is first obtained of the court.

That a system of reviewing our present unscientific method of sentencing is desirable seems clear. A judge in one part of the state may hand down severe penalties in larceny cases and light ones in sex offenses. A judge in another part of the state may do just the reverse. The same judge may follow varying standards in deciding similar cases. Some judges may give much weight to wise sociological considerations. Others may ignore

52. In Christian v. Commonwealth, 5 Metc. 530 (Mass. I843) it was held that the appellate court could only reverse, and that it could not even remit the case to the trial court for a new sentence whether any part of the sentence had been served or not. To the same effect see McDonald v. State, 45 Md. 90 (1876).

53. Howell v. State, I Ore. 24I (I859).

54. See (IgIr) J. CRIM. L. I7O.

55. Burch v. State, 55 Ala. I36 ( 1876 ). That is the rule laid down in the American Law Institute Code of Criminal Procedure, Section 459 ( $I$ ).

56. E. g., IDaHo CODE (1932) \& I9-272I; IOWA Code (I93I) \& I40Io; NeB. CoMp. Stat. (I929) \$29-2308. For a general discussion and collection of other statutory materials, see (I927) 25 MICH. I. REv. 67I ; (I934) 9 WIS. L. REv. I72.

57. Davis v. State, I55 Ark. 245, 244 S. W. 750 (1922), (I923) 32 YALE L. J. 6I9. For a contrary view, see (I927) I3 VA. L. REV. 357.

58. Wallace v. United States, 243 Fed. 300 (C. C. A. 7th, I9I7), cert. denied, 245 U. S. 650 (I9I7) ; Note (r933) 42 YaLE L. J. 453. The old federal circuit courts exercised such power. Bates v. United States, to Fed. 92,96 (C. C. N. D. I11. I88I) ; United States v. Wynn, Ir Fed. 57 (C. C. N. D. Nev. 1882). 
or pay little attention to them. Thus the absence of appellate review makes the treatment of the criminal dependent on the wishes of a single judge, almost invariably untrained in criminology, psychology and psychiatry. In the absence of power to modify sentences, appellate courts are likely to reverse for technical defects in the conviction. ${ }^{59}$

Certainly a system whereby some review is obtained is better than the existing system. To that extent the movement for giving the appellate courts power to review the propriety of sentences is a sound one. The composite view of three or five or seven judges is likely to be far less arbitrary. An appellate court furnishes a permanent central group, so that there is the possibility of the development of standards which may be followed in the trial courts and by the appellate court itself with something like consistency.

If the appellate court is to have the power to modify the sentence, it should have the power to increase as well as decrease. ${ }^{60}$ This is the rule in England when appeal is from the sentence. ${ }^{61}$ In Scotland it may be increased even when appeal is from conviction. Two functions are thus served: more complete standardization is secured, and frivolous appeals are discouraged.

That review of propriety by appellate courts may develop a certain amount of standardization may be granted without approving of such review. In the first place, experience has shown that appellate courts do not follow their own standards. In the second place, since the law gives the trial court a certain amount of discretion in fixing the sentence, no amount of standards laid down by the appellate court will bind the trial court very closely. But the biggest objection is that appellate courts as well as trial courts are wholly unsuited by training and methods of work to pass on the propriety of sentences, whereas they are eminently fitted to pass on the correctness of the conviction of the defendant. It is their peculiar province to enforce compliance with the rules of substantive law and procedure.

But the problem of sentencing involves wholly different considerations. ${ }^{62}$ The question no longer is, is the defendant guilty or innocent? but, what shall be done with him? In considering what shall be done with

59. Minnesota Crime Comm. Rep. (Ig26-1927) 37.

The American Law Institute Code of Criminal Procedure, Section 459 (2) permits the appellate court only to reduce the sentence. Efforts to allow the court to increase were defeated. (I930) 8 Proc. Am. L. Inst. 267. The Report on Unfairness in Prosecutions (I93I) 345 , would allow the appellate court to reduce the sentence. 566,574 .

60. Gemmill, Report of Committee E of Institute of Criminal Law (rgI2) 3 J. Crrar. L.

6r. Sentences were increased from twelve to fifteen years penal servitude in the case of a dangerous assault, Rex v. Simpson, 75 J. P. 56 (Crim. App. I9I0); and from three to five years for arson where the wife and children were in danger of their lives. Rex v. Martin, 20 Crim. App. Rep. I87 (Ig28).

62. The power of an appellate court to modify has, however, been held not to involve an encroachment on the pardoning power. Palmer v. State, $70 \mathrm{Neb}$. 136, 139, $97 \mathrm{~N}$. W. 235, 236 (I903), (I904) I7 HARv. L. Rev. 279. 
the defendant, attention must be given to the several objectives of the administration of the criminal law. Society must be protected. Other persons must be deterred from the commission of offenses. The defendant must be reformed so that he will henceforth be a good citizen. Perhaps the courts may adequately accomplish the first objective, that of protecting society. That is by no means clear, however. A court has little more than the type of crime committed to use as a basis for determining the penalty. ${ }^{63}$ Yet criminologists are aware that many who have committed the most serious crimes never repeat, while some of the lesser offenders are a constant prey on society. When sentencing is by courts society is likely to have either too little or too much protection from the criminal.

The imposition of the penalty by the courts may be somewhat satisfactory from the point of view of deterring other criminals. It is by no means clear that it is the nature of the penalty that deters others from crime. If it be true that it is the certainty and the promptness with which the defendant is brought to trial, rather than the amount of punishment that deters the criminal, it can make little difference whether the penalty is imposed by a court or by a non-legal tribunal. A certain amount of deterrence, however, might come from the use of the latter that would not come from the use of the regular courts. Since such a tribunal could suit the penalty to the offender, a lesser offender would be aware of the fact that he might be kept in prison as long or longer than a serious one. He could not get his freedom merely by "doing his time".

It is probably from the point of view of treating the criminal to secure his rehabilitation, thus at the same time protecting society, that the courts fall down most seriously. ${ }^{64}$ The ordinary trial judge tries criminal cases only part of the time. He must be familiar not only with the rules of substantive criminal law and criminal procedure and evidence but also with the rules of the civil law. In the nature of things he can know but very little about sociology, psychology, and psychiatry. Yet it is upon these fields of learning that we must draw if we are to individualize the treatment of criminals successfully. A century ago there were no such bodies of knowledge available for sentencing purposes. Today, though the gaps in such knowledge are admittedly great, it is believed that we have much that is useful.

Is not the way out to be found in separating the guilt finding and sentencing function and in the creation of a disposition tribunal to perform the latter function? Create a disposition tribunal of perhaps six to nine

63. In some states, such as Massachusetts, however, the judge has before him the report of the probation officer on the defendant before passing sentence for a serious offense.

64. Ensor says that judges forge "blindly and needlessly, in the exercise of their untutored free will, the little cruel sequences which turn a redeemable criminal into an irredeemable one." Courts AND Judges (1933) 86. Sir Henry Hawkins is quoted in Train, The PrisONERS AT THE BAR (I923) as saying: "Experience, however, has told us that the profoundest lawyers are not always the best administrators of the criminal law." 
members appointed by the governor. ${ }^{65}$ Have two or three lawyer members and four or six who are not lawyers, and have one of the lawyers the executive head of the tribunal. The presence of these lawyer members will keep the tribunal from taking action in an extreme way. To facilitate business the tribunal should sit in two or three divisions. It should have such a staff of doctors, psychologists, psychiatrists, social workers and clerks as is necessary to investigate thoroughly the record of each defendant brought before it. It should have jurisdiction to pass sentence upon all defendants convicted in the courts of the state of any crime except violations of health and safety regulations. A conservative grant of power to it would permit it to impose upon a defendant any sentence now authorized by law for the crime of which he was convicted. It should have the power to change the sentence as the acts of the defendant may require, and it should have jurisdiction over parole.

The rights of the defendant may be safeguarded by permitting argument by him or his lawyer and by allowing him to hear or inspect all evidence. The tribunal should, however, be permitted to secure evidence by the reports of its staff or other persons as well as from witnesses in court. A final safeguard would be to permit review by the appellate court for corruption, arbitrariness and lack of support in the evidence. ${ }^{66}$ Such review would thus be wholly distinct from the review of the propriety of sentences now existing in a number of states, in the English Court of Criminal Appeal, and as proposed in the American Law Institute Code of Criminal Procedure. The appellate court would not be called upon to apply and evaluate non-legal standards wholly unfamiliar to it. That function would be performed by the disposition tribunal. The appellate court, just as in passing on convictions or on civil cases, would apply purely legal considerations. The specialized juridical character of the appellate court would be conserved. It would no longer have to perform a non-legal function, and perform it badly, as in the past.

The advantages of the disposition tribunal may be briefly summarized. It will secure greater expertness in sentencing, since it will have a technique

65. The writer is indebted for the plan set out to the discussion in the seminar on Administration of Criminal Justice at the Harvard University Law School conducted by Professor Sam Bass Warner. For other discussions see: Salemles, The Indrvidualrzation of Punishment (igit tr.) 227; Poland \& Cohen, The Criminal Appeal Examined (1906) 6; Schlapp \& Smith, New Criminology (1928) 257; Sheldon Glueck, Principles of a Rational Penal Code (Ig28) 4I HARv. L. Rev. 453, 473; Willoughry, PRINCIPLES of Judicial Administration (I929) 55I; Ensor, Courts and Judges (1933) 90; Sayre, Crime and Pumishment (1928) I4I ATt. MoNTHLY 735, 746; Report ON PENAL Institutions Probation \& Parole (I93I) Nat. Comm. ON Law Observance and Enforcenent I44; Report on Prosecution (I93I) Nat. Comm. on LaW ObServance aNd Enforcensent I66; Alfred E. Smith, N. Y. Times, Dec. 8, I927, at I; Glueck, Mental Disorder and the CrIminal LAW (1925) 485; Glueck, Psychiatry and the Criminal Law (Ig28) I4 VA. L. REv. 155, 177; Glueck, Significant Transformations in the Administration of Criminal Justice (I930) I4 Mental Hygiene 280, 297; Randall, Proceedings Following Conoriction (Ig12) 3 J. CRIAT. L. 5 I7.

66. Glueck, Principles of a Rational Penal Code (1928) 4I HARv. L. REv. 453, 479, n. 32. 
which judges do not have. The tribunal, as a result of its own experience over a period of time and with a large number of cases, will increase its expertness. The writing of opinions by the tribunal will develop sound principles of sentencing, whereas under the existing system sentences are unmotivated. The disposition tribunal will do away with the conflict between the judge and the parole board, as it will perform the functions of both. Convictions would be easier to obtain, as the jury and trial court would have only the guilt element to deal with. Finally, it would relieve the appellate courts of work for which they are wholly unsuited.

\section{Review of Questions Not Properdy Raised and Preserved}

In the discussion thus far review of errors where the question was raised and preserved in the trial court has been considered. Attention is now turned to the problem of review where the defendant has failed to raise and preserve the question in the trial court.

The general rule governing appellate procedure is that the court will refuse to consider questions not raised below. ${ }^{67}$ This is said with the greatest emphasis and frequency in civil appeals. It is said in a less emphatic vein in criminal appeals. A number of reasons are assigned. If the defendant had raised the question in the trial court, the error might have been cured then and there. Why should the appellate court give him relief he might have obtained in the trial court? If a defendant could have any new point considered, he might withhold it from the trial court in order to secure a reversal in the upper court with its attendant delay. Furthermore, it seems inequitable to the trial court to chalk up a reversal against it when it was given no opportunity to correct its error. But the basic theory seems to be the prevalent conception of the function of appellate courts. The business of appellate courts is conceived of as being not to consider cases on their merits but to correct the errors of the trial court. If the question was not presented to the trial court no error was committed by the trial court, hence there is nothing to review. ${ }^{68}$ Thus, the term error is given a peculiar connotation in the appellate court. The trial court, in fact, may have erred in a given ruling: ${ }^{69}$ But since it was not objected to, the appellate court cannot review it. For the appellate court it is not error. Error for the trial

67. Materials illustrating this trend are collected in (I9I6) 16 CoL. L. REv. 680; (I922) 36 HARv. L. Rev. I03; (I928) 38 YaLE L. J. 255. The entire problem is excellently dealt with by Campbell, Extent to Which Courts of Review Will Consider Questions Not Properly Raised and Preserved (I932-I933) 7 Wis. L. REv. 9I, I60; 8 WIs. L. REv. I47.

68. Chancellor Kent said that "the very theory and constitution of a court of appellate jurisdiction only, is the correction of errors which a court below may have committed, and a court below cannot be said to have committed an error when their judgment was never called into exercise, and the point of law was never taken into consideration." Gelstan v. Hoyt, I3 Johns. 56I, 576 (N. Y. I8I6).

69. There may be two sorts of errors in the trial court. It may err when all the facts and legal questions are presented to it and it arrives at its decision with these in mind. It may err because not all the facts are presented to it, its decision being correct on such facts as it has knowledge of. The former is the usual type of error. 
court is one thing; error for the appellate court, another. The defendant may find himself out of court in the upper court although the trial below was riddled with prejudicial errors from beginning to end.

Before going any further it may be well to ask, how might the defendant have raised and preserved the question below, so he could have avoided all these difficulties? The defendant's attorney should keep in mind from the beginning of the trial the possibility of an appeal. He should present every question having a material bearing upon the defense of the defendant to the trial court. He may do this by plea, or motion, or by an objection, depending on the nature of the question. In some cases an exception or a motion for new trial is necessary. ${ }^{70}$ The ground of the objection should be specified, except where the error is perfectly patent. Then if the defendant takes an appeal, he must proceed to have the matter relating to the questions raised incorporated in the record for review. ${ }^{\mathbf{7 1}}$ The papers which form a part of the ancient record or the "record proper" may go up as they are. But all other matter must be made a part of an approved bill of exceptions or its statutory counterpart. When the case reaches the appellate court the appellant should raise the questions in that court by making an assignment of errors. Such assignment is intended to raise the claims of the appellant in a logical, orderly fashion. It should be supported by a brief containing argument and authority. When the steps outlined above have been taken, there can then be no question of the right to have the questions passed on by the appellate court.

But all or some of these steps are frequently omitted. The appellate court then has to consider whether or not it will relieve the defendant from the omissions of his attorney and consider the questions anyhow. In the absence of any statutory restriction the appellate court has the power to consider the questions. ${ }^{72}$ Some courts rest the power on the general authority to supervise the inferior courts. ${ }^{73}$ Others put it on the single duty of all courts to administer justice. ${ }^{74}$ The power itself is clear. The real problem is, when should the power be exercised? Some courts view the

70. There has been considerable debate in recent years over the requirement that exceptions be taken. A number of authorities have thought the need of noting exceptions often works injustice. Cardozo, AMIERTCa Speaks (I928) 67; RePort on LawLessness in LAw

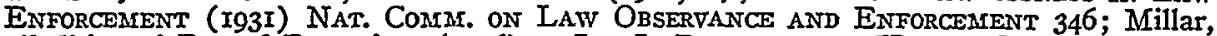
Abolition of Formal Exceptions (I9I6) Io Ir工. L. REv. 437, 439; HARRIS, OHIO ApPELLATE COURTS AND PROCEDURE (1933) 154. On the other hand little attention is often paid to an objection, whereas if an exception is noted, serious effort is made to eliminate the error. ULMAN, A JUdGe TAKES THE StaNd (I933) 264. In the view of Medina, Shall New York Surrender Leadership in Procedural Reform? (I929) 29 CoL. L. REv. 158, I72, the problem has not been sufficiently studied.

7x. A failure to do so may result in the appeal being treated as frivolous. (I928) 28

CoL. L. Rev. 483.

72. Ohama v. State, 24 Wyo. 513, I6I Pac. 558 (I9I6). (1875).

73. People v. Murray, 72 Mich. Io, 40 N. W. 29 (I888) ; Bishop v. State, 43 Tex. 390

74. People v. Weiss, 129 App. Div. 671, 678, II4 N. Y. Supp. 236, 242 (2d Dep't 1908). 
problem as one of discretion. ${ }^{75}$ But not all courts take this view. The New York Court of Appeals cannot review questions in criminal cases not raised below, except in capital cases. ${ }^{76}$ The New York rule, however, is based on its own peculiar constitutional provision and statute.

Since the duty to review rests in the discretion of the court, no set rules can be laid down as to when questions will be reviewed. Questions which arise only after the case has gotten into the appellate court, ${ }^{77}$ such as the jurisdiction of that court, may be reviewed. The appellant may also present new arguments when the point itself was properly presented and preserved; he is not confined to the arguments he made below. A number of civil cases permit the appellee to raise new questions to support the judgment below. If a new contention is made on review and is met in the brief and oral argument on the other side, the court is likely to review the objection. Occasionally, the courts utter what perhaps are dicta for the sake of determining principles of law for future cases.

One of the clearest cases for review where objections were not taken below is the jurisdiction of the trial court. ${ }^{78}$ In civil actions the question of venue does not go to the general jurisdiction of the court. But in a number of jurisdictions venue in criminal actions has been held to go to the jurisdiction of the court, and it may therefore be raised on review. ${ }^{79}$ In most jurisdictions the defendant may also raise the objection that the indictment or information fails to charge an offense. ${ }^{80}$ This has been occasionally carried to the extreme of reviewing a defective description of parties in an indictment. ${ }^{81}$ While it is commonly said that the constitutionality of statutes will, as in civil cases, not be considered in criminal cases, ${ }^{82}$ there are many cases permitting it. ${ }^{83}$ In a number of criminal appeals the defendant has been allowed to show that he was not given constitutional rights, such as a

75. State v. Taylor, 32 N. M. 163, 252 Pac. 984 (1927). In an earlier case the New Mexico court on rehearing after a petition for the recall of the judge had been circulated decided that it had the common law power to do justice. State v. Garcia, I9 N. M. 414, I43 Pac. IOI2 (1914), discussed in Sunderland, The Proper Function of an Appellate Court (I930) 5 IND. L. J. 48I, 494.

76. N. Y. Const., Art. VI, §9; N. Y. Code of Crim. Proc. 528; see (Ig28) 28 Cot. L. REv. 980 .

77. But cf. Tari v. State, II7 Ohio St. 48I, I59 N. E. 594 (I927), (1928) 23 ILL. L. REv. 394, where although the United States Supreme Court had held the criminal statute invalid as to another defendant after the conviction of the defendant, the Ohio Supreme Court said that there could be no review as the defendant had not raised the point below. The cases are in conflict as to insanity. Weimofen, Insanity as a Defense IN CrIminal Law (1933) 394.

78. State v. Wyatt, 207 Iowa 322,222 N. W. 867 (I929).

79. Johnson v. State, 7 Ga. App. 55I, 67 S. E. 224 (I9ro) ; People v. Warner, 20I Mich. 547, 167 N. W. 878 (I9I8). Contra: Ryan v. United States, 285 Fed. 734 (C. C. A. 5th, r922) ; State v. Holder, 133 N. C. 709, 45 S. E. 862 (1903).

80. Connley v. United States, 46 F. (2d) 53 (C. C. A. 9th, r93I) ; State v. Dolan, 58 W.

Va. 263, 52 S. E. I8I (I905). Contra: State v. Sheki, I25 Kan. I Io, 263 Pac. 787 (I928),

8I. People v. Smith, 258 IIl. 502, Ior N. E. 957 (I9r3); State v. McCollum, r8I N. C. 584 , 107 S. E. 309 (1921).

82. (I933) 8 IND. L. J. 328.

83. State v. Pugh, 31 Ariz. 317, 252 Pac. I018 (I927) ; State v. Rawls, 16r La. 628, 109

So. 146 (1926); (1933) 33 CoL. L. REv. 692. 
public trial, ${ }^{84}$ freedom from double jeopardy, ${ }^{85}$ or a jury trial. ${ }^{86}$ Occasionally, the courts go so far as to protect purely statutory rights of the defendant, such as the illegality of the venire of a grand jury. ${ }^{87}$ In civil cases errors in the instructions of the court must be brought to the attention of the trial court, but a number of criminal cases have held that the trial court must give the whole law to the jury though no exception is taken. ${ }^{88}$ Misconduct of the prosecuting attorney, where the error is incurable, is a ground. ${ }^{89}$ The same is true as to misconduct of the trial judge. ${ }^{90}$ Improper questions asked by the jury have occasionally been held a ground. ${ }^{91}$

The courts show a greater liberality in criminal cases than in civil cases. This is particularly true as to questions of rights, privileges, and immunities, and as to the constitutionality of statutes upon which the proceedings are based. Capital cases receive the most liberal treatment. ${ }^{92}$ Other cases, particularly felonies, where the penalty is very severe are often similarly dealt with. ${ }^{93}$ Incompetency of counsel is sometimes made a ground in criminal cases. ${ }^{94}$ Considering questions not raised below on review in criminal cases where it is clear that there has been a miscarriage of justice has reached its greatest development in the federal courts and the New York Appellate Division. ${ }^{95}$ In military law the whole case goes up without objection or exception being taken. ${ }^{96}$

In a number of jurisdictions there are statutes which appear to extend the right or duty to consider new questions. For instance the Federal Judicial Code provides: ${ }^{97}$

"On the hearing of any appeal, certiorari, writ of error or notice for a new trial, in any case, civil or criminal, the court shall give judgment after an examination of the entire record before the court without regard to technical errors, defects, or exceptions which do not affect the substantial rights of the parties."

84. State v. Marsh, I26 Wash. I42, 2I7 Pac. 705 (I923).

85. Belter v. State, I78 Wis. 57, I89 N. W. 270 (I922).

86. State v. Tallken, 316 Mo. 596, 292 S. W. 32 (I927).

87. Trammell v. State, I5I Ala. I8, 44 So. 201 (I907).

88. English v. Commonwealth, $216 \mathrm{Ky} .608,288$ S. W. 320 (I926) ; Gonzales v. State, 35 Tex. Cr. App. 339, 33 S. W. 363 (I895).

89. People v. Simon, 80 Cal. App. 675, 252 Pac. 758 (1927).

90. Benedict v. State, I90 Wis. 266, 208 N. W. 934 (I926).

91. State v. Sickles, 220 Mo. App. 290, 286 S. W. 432 (1926). Contra: State v. Crawford, 96 Minn. 95, 104 N. W. 822 (I905).

92. Schlencker v. State, 9 Neb. 300, 2 N. W. 7 ro (1879) ; Ohama v. State, 24 Wyo. 513, I6I Pac. 558 (1916). Contra: State v. Turner, 36 S. C. 534, I5 S. E. 602 (1892); Fisher v. State, I08 Tex. Cr. App. 623, 2 S. W. (2d) 249 (I927).

93. People v. Murray, 72 Mich. Io, 40 N. W. 29 (I888) (fifty year term for rape).

94. People v. Gardiner, 303 Ill. 204, 135 N. E. 422 (I922); Lloyd v. State, I5 Okla. Cr. App. 130, 175 Pac. 374 (1918). See Note (1923) 7 I U. of PA. L. REv. 379.

95. Sykes v. United States, 204 Fed. 909 (C. C. A. 8th, 1913) ; People v. Weiss, I29 App.

Div. 67I, II4 N. Y. Supp. 236 ( 1908 ).

96. Underhill, Notes on the Procedure of Courts-Martial (Igrg) ro J. Crim. L. 42, 47. 97. 28 U. S. C. A. \$39I (I926). 
This statute was held by most of the lower federal courts not to compel an examination of questions not raised, but to leave such examination in the discretion of the court. ${ }^{98}$ A number of the states have statutes of general scope which might be, and have sometimes been, construed to impose a duty on the reviewing court to consider questions not raised below. ${ }^{99}$

In order to have a question reviewed it has been seen that it should be saved below. It is also essential that it be properly presented in the appellate court. This involves two steps. The appellant must first make an assignment or specification of errors. He must then support his contentions by a brief setting forth arguments and authorities. The first step is generally taken in one of two ways. The appellant may make a separate assignment of errors, ${ }^{100}$ or he may assign errors in his brief. The object of such assignment is to assist the state and the appellate court. In some jurisdictions statutes or court rules allow the court to consider "plain errors" not properly assigned. The courts are as free to consider unassigned errors as errors not raised and preserved below. In several states statutes have been construed to require review even though no assignment of errors nor a brief is filed, and though there is no appearance of counsel on behalf of the defendant.

Where the appellant fails to support his contentions by argument and authority in his brief the rule in civil appeals is to treat this as a waiver of the error. The appellant may not insist on such error in oral argument. However, the courts are as liberal in considering questions not argued in the briefs as in considering questions not raised below. In a number of states statutory provisions are construed as requiring the court to examine the record in criminal cases and review all points raised below although no argument is made on these points. ${ }^{101}$ On the other hand, there are decisions, such as that of the California Supreme Court, affirming a judgment sentencing a defendant to life imprisonment without examining the record, where no briefs had been filed. ${ }^{102}$ As a rule there can be no rehearing in the appellate court where the question might have been raised at the original hearing. But the courts have been more liberal in criminal cases. ${ }^{103}$

98. Bilboa v. United States, 287 Fed. I25 (C. C. A. 9th, I923) ; Feinberg v. United States, 2 F. (2d) 955 (C. C. A. 8th, 1924) overruling August v. United States, 257 Fed. 388 (C. C. A. 8th, rol8).

99. Campbell, Extent to Which Courts of Review Will Consider Questions Not Properly Raised and Preserved-Part III (I933) 8 WIS. I. REv. I47, I48-I5I.

100. Assignments of error have long been abolished in England. It has been said in criticism of them that they are still used for purely historical reason that the judge was held to be entitled to know what were the charges against him. Sunderland, Improving the Administration of Justice (I933) I67 ANNALS 60, 6r.

Ior. Clemmons v. State, 22 Ala. App. 4I8, II6 So. 91o (1928) ; Martinez v. State, 20 Ariz. 29, I76 Pac. 582 (I9I8) ; State v. Hjerpe, I09 Minn. 270, I23 N. W. 474 (rg09); State v. Headby, I8 S. W. (2d) 37 (Mo. 1929).

I02. People v. Busby, Ir3 Cal. I8I, 45 Pac. I9r (I896). But, in People v. Clark, I2I Cal. 633, 54 Pac. I47 (I898), where the sentence was death, the errors were reviewed.

I03. Quertermous v. State, 95 Ark. 48, 60, I27 S. W. 95I, 956 (19I0); State v. Holbrook, 98 Ore. 43, 8r, I88 Pac. 947, 192 Pac. 640, I93 Pac. 434 (I920). 
The American Law Institute Code of Criminal Procedure lays down a rule of review as to questions not raised and preserved nor properly presented to the appellate court which seems to give the defendant ample protection. ${ }^{104}$ The appellate court is to review all rulings and orders appearing in the appeal papers in so far as it is necessary, even though no exceptions were taken in the trial court. It is to review instructions, provided that an objection was made and it was alleged as a ground of appeal. Finally, to avoid all hardships on defendants it may review any other things said or done in the cause which appear in the appeal papers, including instructions to the jury, if the court deems that justice requires it. The proposed rules governing federal criminal appeals submitted to the Supreme Court provide that any ground for reversal appearing in the record, transcript or condensed statement may be reviewed in the interests of justice. ${ }^{105}$

On superficial analysis, whenever there is a failure to raise and preserve objections in certain types of cases, the appellate court should consider the objection, and that is the end of the matter. But something much deeper is involved. The time of the appellate court is not to be frittered away considering questions which might have been raised earlier. The bar of the jurisdiction should be of such a character that such mistakes will rarely occur. When such mistakes do occur they are usually to be assigned to the incompetence or negligence of the defendant's attorney. The appellate court should not be compelled to add to its labors because of the bungling of improperly trained lawyers. In civil cases clients are often made to suffer for the ignorance of their attorneys. In criminal cases this is unthinkable. But the way out is not simply in review of objections not raised, but in improving the bar so that the objections will be raised and preserved.

104. $\S 457(x)$.

I05. Rule X. 